sprawie odpowiedni reskrypt" (s. 49). Tymczasem sprawę języka w nauczaniu religii i języka polskiego regulował ukaz z 1864 oraz rozporzadzenia z 1871 i $1885 \mathrm{roku}^{3}$. Zagadnienie to jest dostatecznie znane i nie widzę potrzeby, by tutaj je omawiać. Należało jednak w omawianej monografii, chociażby w paru zdaniach, przedstawić poziom alfabetyzacji ludności chłopskiej w tym czasie. Jej stan ukazałby ogrom wysiłku, jaki Liga Narodowa, jej agendy a i sam Zawadzki musieli włożyć w prace nad uświadomieniem i upolitycznieniem ludu. Niski poziom cywilizacji w znacznym stopniu tłumaczył obawy ludnosci wsi przed powrotem wolnej już, ale ,pańskiej Polski”, które w pewnych kręgach utrzymywały się do końca I wojny.

Autor zbyt mało miejsca przeznaczył na przedstawienie idei solidaryzmu narodowego, która, jak wiadomo, była jednym z filarów endeckiej doktryny. A ona to m.in. tlumaczy różnice podejścia narodowych demokratów do walki młodzieży polskiej o nauczanie religii $w$ jezyku ojczystym w 1902 r. i tzw. "strajku szkolnego" w 1905 r. Poparcie i pozytywna ocena wystapień uczniów Podlasia i Polesia przez Ligę Norodowa spowodowana była głównie tym, że akcja ta była dobrze przygotowana (przez działaczy z organizacji „IKS"), miała realne szanse powodzenia i ograniczyła się do murów szkolnych. Natomiast negatywny, by nie powidzieć wrecz wrogi stosunek (szczególnie w pierwszym okresie), do strajku szkolnego z 1905 r. wynikał z obawy przed zaangażowaniem się młodzieży w rewolucję, której przebiegu i rezultatów nie można było w żaden sposób przewidzieć ${ }^{4}$. Przywódcy Ligi zostali zaskoczeni postawą młodzieży i w sytuacji ,przyciśniętych do muru", w obawie przed możliwością calkowitego braku kontroli nad reakcjami młodzieży, zmuszeni zostali do jego akceptacji i powołania Związku Unarodowienia Szkól ${ }^{5}$.
Trzežwa kalkulacja oraz realizm w ocenie narodowych poczynań były zasadniczym kryterium wartości politycznej aktywności kierownictwa Ligi. Wykształcenie tych właśnie cech było podstawowym zadaniem prac wychowawczo-programowych narodowego obozu. Cech tych jednak brakowało Aleksandrowi Zawadzkiemu, co ukazal Autor w rozdziale piatym.

Na zakończenie chcę zaznaczyć, że praca Jana Konefała z pewnościa zasługuje na uwagę. Jednocześnie w pełni podzielam pochlebną opinię prof. J. Szaflika, zamieszczona na okładce ksiażki, o solidnej i szerokiej bazie źródłowej. Walory pracy podnosi 20 aneksów. Ich lektura pozwala, w pewnym chociażby stopniu, wczuć się w szczególna, a jakże ważna dla Polski, atmosferę czasów, w których przyszło działać Aleksandrowi Zawadzkiemu.

Eugeniusz Paruzel

I Do tej pory problematyke te najpełniej przedstawil T. Wolsza w pracy Narodowa Demokracja wobec chlopów 1887-1914. Programy, polityka, dzialalność. Warszawa 1992.

2 Por. T. Kulak, Jan Ludwik Poplawski 1854 - 1908. Biografia polityczna. Wrocław 1989.

3 R. Kucha, Oswiata elementarna w Królestwie polskim 1864-1914, Lublin 1982, s. 20-21, 29-30. Patrz też: H. Brodawska, Ruch chtopski po uwlaszczeniu w Królestwie Polskim 1864-1904, Warszawa 1967; J. Molenda, Chtopi Naród Niepodlegtość. Ksztatrowanie się postaw narodowych i obywatelskich chtopów w Galicji i Królestwie Polskim w przededniu odrodzenia Polski, Warszawa 1999. W przypisie 2 i 4 na s. $49-50$ bibliografia na ten temat.

4 R. Dmowski, Szkola i spoleczeństwo. Z powodu tzw. Strajku szkolnego w Królestwie. Kraków 1905.

5 Z. Wasilewski, Proces Lednickiego, Warszawa 1924, s. 381 - 382; E. Pruzel, ldeal wychowawczy Narodowej Demokracji i próby jego realizacji na przelomie XIX $i$ XX wieku, Toruń 1993. W tym miejscu chciałbym admienić, że jestem $w$ trakcie przygotowywania pracy o wychowawczym oddziaływaniu N D przełomu wieków na społeczístwo.

\title{
Aldona Ossowska, Moralistyka okresu Wczesnego Cesarstwa Rzymskiego wobec problemów wychowania w rodzinie, Byd- goszcz 2001, ss. 220
}

Rodzina jest miejscem, w którym odbywa się proces wychowania naturalnego - pierwotnej i najdawniejszej formy wychowania. Jest to pier- wsze środowisko, grupa społeczna, której wpływy determinuja pewne umiejętności i nawyki, kształtuja postawy, przekazuja wartości. Początkowo, 
jedynymi, głównymi nauczycielami (opiekunami - wychowawcami) sa dla dziecka rodzice, a tworzone przez nich środowisko wychowawcze i stosunki panujące $\mathrm{w}$ rodzinie decyduja o jakości życia uczuciowego i społecznego przyszłego dorosłego człowieka.

Nauce historycznej przypada ważna rola, w polskich badaniach ciagle niewystarczajaco eksponowana, ukazania przemian, jakie zachodziły w rodzinach - zasadach ich tworzenia, składzie, wzajemnej zależności i pozycji poszczególnych członków, socjalizacji oraz funkcjach spełnianych $w$ przeszłości. Wyniki współczesnych ustaleń dotyczących wychowania $w$ rodzinie starożytnej pobudzaja do refleksji oraz uczą pedagogów i historyków wychowania pokory wobec wypracowanych $w$ antyku wzorów modeli, teorii dotyczacych szeroko pojętej edukacji rodzinnej.

Prezentowana książka jest wynikiem badań A. Ossowskiej nad poglądami Diona Chryzostoma, Plutarcha z Cheronei i Pliniusza Młodszego wyrażającymi ich zapatrywania wychowawcze. Autorka znakomicie usystematyzowała, zawarte w pismach wymienionych filozofów, refleksje dotyczace koncepcji malżeństwa oraz roli kobiety $w$ tym zwiazku, pozycji dziecka w rodzinie i jego roli w kształtowaniu środowiska wychowawczego, określenia ról i zadań wychowawczych ojca oraz matki, a także oddziaływań wychowawczych innych krewnych i osób mających udział $w$ edukacji domowej dzieci.

Z treści ksiażki, o której mowa, dowiadujemy się, w jakim zakresie dorobek myśli Diona Chryzostoma, Plutarcha i Pliniusza Młodszego dotyczący wychowania $w$ rodzinie mieści się w nurcie moralistyki.

Niewątpliwym osiagnięciem badawczym prezentowanej monografii jest oryginalność, drobiazgowość oraz wszechstronność analizy historycznej źródeł: osiemdziesięciu, zróżnicowanych swą tematyka, forma retoryczną i stylistyka mów Diona; Moraliów i biografii Plutarcha; Listów oraz Panegiryku Pliniusza Młodszego. Nie bez znaczenia jest także fakt, iż w przypadku twórczości Diona, poza historyczno-literacka monografia M. Szarmacha (Dion z Prusy. Monografia historyczno-literacka, Torun 1978) w polskiej literaturze naukowej brakuje całościowej syntezy poświęconej tematyce rodzinnej i wychowaniu w poglądach retora $\mathrm{z}$ Prusy. W tym zakresie recenzowana ksiażka niewatpliwie wypełnia istniejąca lukę badawczą.

Autorka podzieliła pracę na cztery rozdziały. Pierwszy $z$ nich zatytulowany Moralistyka a horyzonty zycia intelektualnego na przetomie I/II wieku w Cesarstwie Rzymskim, prezentuje kontekst kulturalno-literacki oraz intelektualny działalności i twórczości omawianych autorów. Ukazuje też swoistości ich biografii oraz wynikajace z tego zróżnicowanie sposobu uprawiania moralistyki i kręgów oddziaływania. Drugi Rodzina a horyzonty zycia spotecznego w Cesarstwie Rzymskim na przetomie $I / I I$ wieku, ukazuje rodzinę jako istotny element życia społecznego. W kontekście struktury społecznej Cesarstwa I i II wicku swoje uzasadnienie znajduje ograniczenie analizy życia rodzinnego do elit Imperium. Ze względu na znaczenie i reprezentatywność poglądów Diona Chryzostoma, Plutarcha i Pliniusza Młodszego $w$ omawianym okresie, $w$ rozdziale tym znalazło się omówienie ówczesnego dorobku myśli teoretycznej dotyczacej rodziny i wychowania.

Rozdział trzeci Poglady Diona Chryzostoma, Plutarcha $z$ Cheronei $i$ Pliniusza Młodszego na wychowanie $w$ rodzinie, stanowi zasadnicza analizę pogląów wskazanych moralistów na zadania wychowawcze ojca i matki, akcentuje odmienności tych zadań i przemian, określa również zadania wspólne rodziców. Autorka omawia w nim także pozycję dziecka $w$ rodzinie oraz charakteryzuje oddziaływanie krewnych (wujka, ciotki, rodzeństwa), niańki i pedagoga na jego wychowanie. Rozdział czwarty z kolei, pt. Wptywy greckie a rzymskie w pogladach moralistów na wychowanie $w$ rodzinie okresu Cesarstwa $(I-\| I$ w. n.e. $)$, ukazuje odmienność proweniencji zapatrywań edukacyjnych wywodzacych się $\mathrm{z}$ dwóch tradycji kulturowych. Zawiera syntezę wplywów hellenizacji i romanizacji, wyjaśnia zjawiska asymilacji kulturowej $w$ wychowaniu i pogladach na jego przebieg oraz rodzaj.

Konstrukcja recenzowanej pracy jest przemyślana, konsekwentna i logiczna. Autorka używa ladnego języka, dobrego stylu. Wykorzystana literatura naukowa wykracza daleko poza granice bezpośrednio związane $\mathrm{z}$ tematem.

Swoja publikacja A. Ossowska z cała pewnościa dobrze wpisała się $w$ nurt badań nad rodziną rzymska. $Z$ postawionych sobie zadań badawczych wywiazala się bez zarzutu. Po 
lekturze omawianej książki czytelnik zdobędzje nie tylko pełne rozeznanie co do pogladów Diona Chryzostoma, Plutarcha i Pliniusza Młodszego na temat wychowania $w$ rodzinie, lecz zapozna sie także $\mathrm{z}$ pewnymi uniwersalnymi, ponadczasowymi treściami tkwiącymi w europejskiej kulturze.

Walory pracy podnosi także bogata, rzetelnie zestawiona bibliografia oraz streszczenie $w$ języku angielskim, które umożliwi zapoznanie się z nią także potencjalnemu odbiorcy zagranicznemu. Książka, choć w zamierzeniu swym przeznaczona głównie dla środowiska naukowego (historycy, historycy wychowania, pedagodzy), ze względu na wartka $\mathrm{i}$ interesująca narrację na pewno znajdzie nabywców także wśród niespecjalistów, bywalców księgarń i salonów wydawniczych.

\section{Marian Paluszkiewicz, Jerzy Szews, Słownik biograficzny człon- ków tajnych towarzystw gimnazjalnych w Wielkim Księstwie Poznańskim 1850 - 1918, Wydawnictwo Poznańskiego Towarzyst- wa Przyjaciót Nauk, Poznań 2000, s. 259, ilustr.}

Biografistyka i zagadnienia regionalne to dziś tematy lubiane i poczytne. Prawidłowość tę łatwo zrozumieć, ponieważ większość $\mathrm{z}$ nas lubi ciekawostki z życia innych ludzi. Ostatnimi laty obserwujemy kolejne publikacje o charakterze bardziej lub mniej udanie opracowanego słownika biograficznego. Do grupy wartościowych prac należy opublikowany przez Wydawnictwo Poznańskiego Towarzystwa Przyjaciół Nauk Stownik biograficzny czlonków tajnych towarzystw gimnazjalnych w Wielkim Księstwie Poznańskim 1850-1918. Prac o Wielkopolsce z tego zakresu jest niewiele. Prezentowana książka jest szczególna, bowiem dotyczy okresu zaboru pruskiego, ściślej tajnej działalności polskiej młodzieży w szkołach średnich. W okresie niewoli narodowej konspiracyjne organizacje młodzieży działały na ziemiach trzech zaborów. Ich pierwowzorem byli filomaci wileńscy. Ich hasło „Nauka Ojczyzna Cnota" przyświecało kolejnym pokoleniom spiskującej młodzieży.

W latach zaboru pruskiego wykształcenie średnie Polacy zdobyć mogli tylko w gimnazjach niemieckich. Ich program nie zawierał nauki języka, historii i kultury polskiej. Dlatego też młodzież polska zdobywała wiedzę $\mathrm{z}$ tego zakresu potajemnie, organizujacc $w$ tym celu nielegalne towarzystwa samokształceniowe. W Wielkopolsce najliczniej powstawać zaczęły w latach nasilenia germanizacyjnego i Hakaty, kiedy to znacznie ograniczono nauczanie języka polskiego. Począt- kowo miały różne nazwy, nawiązując często do postaci historycznych. Po 1903 roku zaczęły przyjmować wzorem organizacji gnieźnieńskiej nazwę Towarzystwa Tomasza Zana. Kola przyjęły wspólny statut, program działania i skonsolidowały się terytorialnie. W Poznańskiem koła TTZ funkcjonowały w szkołach średnich, w 21 miejscowościach. Droga samokształcenia realizowały kolejno w czterech działach program polskiej szkoły średniej. Omawiano też zagadnienia społeczno-polityczne, przygotowywano uczniów do przyszłej pracy niepodległościowej. Formalne ujawnienie się kół TTZ odbyło się na zjeździe w Poznaniu w dniu 3 stycznia 1920 roku.

To kilkuletnie samowychowanie i samokształcenie młodzi Wielkopolanie kontynuowali na studiach uniwersyteckich w niejawnym Związku Młodzieży Polskiej, tzw. ZET. Opiekowali się polska emigracja zarobkowa w Niemczech, organizowali drużyny strzeleckie. W ten sposób przechodząc przez tajną szkołe TTZ i ZET w państwie niemieckim uksztaltowała się inteligencja polska. Jej wybitni przedstawiciele położyli ogromne zasługi $w$ utrzymaniu, a nawet rozwoju polskiego stanu posiadania w Poznańskiem $w$ latach zaboru. Oddziaływali na tym polu również na Śląsk i Pomorze. Biogramy tych osób znajdziemy w prezentowanym tomie.

Autorami słownika sa historycy TTZ: Marian Paluszkiewicz i Jerzy Szews. Nieżyjący już M. Paluszkiewicz $(2.02 .1902-24.05 .1982)$ był 